\title{
RADIOCARBON ANALYSIS OF PINUS LAGUNAE TREE RINGS: IMPLICATIONS FOR TROPICAL DENDROCHRONOLOGY
}

\author{
Franco Biondi \\ Scripps Institution of Oceanography, Geosciences Research Division, University of California-San Diego, \\ La Jolla, California 92093-0244, USA. Email: fbiondi@ucsd.edu \\ Julianna E Fessenden \\ Department of Biology, University of Utah, 257 S 1400 E, Salt Lake City, Utah 84112-0840, USA
}

\begin{abstract}
A promising species for tropical dendrochronology is Pinus lagunae, a pine tree found in Baja California Sur (Mexico) around lat $23.5^{\circ} \mathrm{N}$. In 1995 , we sampled a total of 27 wood cores from 13 Pinus lagunae trees in Sierra La Victoria $\left(23^{\circ} 36^{\prime} \mathrm{N}, 109^{\circ} 56^{\prime} \mathrm{W}\right)$, just north of Sierra La Laguna, at an elevation of $1500-1600 \mathrm{~m}$. Selected trees were locally dominant, but their ring-width patterns could not be crossdated. To test the hypothesis that visible growth layers in Pinus lagunae are formed annually, we measured radiocarbon amounts in individual rings by means of accelerator mass spectrometry (AMS). Twenty-three ${ }^{14} \mathrm{C}$ measurements were used to trace the location of the 1963-64 "bomb spike" in 3 wood increment cores. By comparing the location of that $\Delta^{14} \mathrm{C}$ extreme with the number of visible radial wood increments, it was possible to conclude that 2 cores had a number of locally absent rings, while the 3 rd one included a few years with more than one growth layer. Therefore, ring-width patterns of sampled Pinus lagunae were not consistent from one tree to another, most likely because of climatic regime in combination with microsite features. While the possibility of generating Pinus lagunae tree-ring chronologies cannot entirely be ruled out, the development of dendrochronological proxy records of climate from coniferous species in tropical North America should focus on species and sites that experience a more pronounced seasonality.
\end{abstract}

\section{INTRODUCTION}

Current widespread concern over future changes in climate stresses the need for long-term yet annually resolved climatic histories. Tropical regions are among the areas of the globe where long instrumental records of climate are scant, even though the tropics are the epicenter of the global hydrological cycle (Berner and Berner 1987). At the Western North American interface between tropical and subtropical regions, precipitation variability is greatly dependent on tropical Pacific forcing. In the winter, El Niño conditions are associated with increased rainfall in a region stretching longitudinally from Southern California and Baja California to Western Texas and the southeastern United States (Diaz and Kiladis 1992; Stahle and Cleaveland 1993). In the summer, monsoonal activity brings heavy rainfall northward from the tropical eastern Pacific over the Gulf of California into Arizona and New Mexico, with largest monthly rainfall amounts occurring along the western slopes of the Sierra Madre Occidental (Douglas et al. 1993; Adams and Comrie 1997). Because of those two processes, the tropical portion of the North American Cordillera is characterized by a pronounced latitudinal transition in precipitation regime: going southward from the United States into Mexico, climate changes from a winter-wet summer-dry pattern in subtropical Southern California, to a winterdry summer-wet pattern in tropical Nueva Galicia - the Mexican coastal states of Jalisco, Colima, and Nayarit (Rzedowski and McVaugh 1966; Mosino and Garcia 1974; Metcalfe 1987).

At interannual to interdecadal scales, proxy records of climate in mid-latitudes can be derived from exactly dated, annually resolved tree-ring chronologies (Fritts 1976). Teleconnections with tropical phenomena, such as ENSO, can also be used for dendroclimatic reconstruction (Diaz and Markgraf 1992; Stahle et al. 1998). To date, dendrochronological studies of tropical trees have been limited by the fact that xylem growth is either uninterrupted or that growth layers are not visually identifiable (Bormann and Berlyn 1981). Some success has been obtained using selected species, mostly from mountainous areas (D'Arrigo et al. 1994; Buckley et al. 1995; Biondi et al. 1999), but paleoclimatic information from tropical terrestrial environments is still extremely scarce, particularly in North America. 
A promising species for tropical dendrochronology is Pinus lagunae, a pine tree found in Baja California Sur around lat $23.5^{\circ} \mathrm{N}$ (Perry 1991). The natural range of the species occupies an area that is intermediate, both latitudinally and climatologically, between Southern California and Nueva Galicia. Rain falls mostly from July to October, but a second wet period occurs in December-January (Díaz 1995). Preliminary research has suggested that the species can be used for dendrochronological studies (Díaz et al. 1994), even though the establishment of a reliable master tree-ring chronology has been problematic (personal communication, TH Swetnam, Laboratory of Tree-Ring Research, University of Arizona, Tucson). To test the hypothesis that visible growth layers in Pinus lagunae are annual rings, we applied radiocarbon dating by means of accelerator mass spectrometry (AMS ${ }^{14} \mathrm{C}$; Bowman 1990). For this purpose, the $\Delta^{14} \mathrm{C}$ record from 1950 to the present is remarkably consistent in the atmosphere as well as in organic matter (including terrestrial vegetation and tree rings), showing a spike in 1963-64 (the "nuclear bomb effect"), and an exponentially decreasing pattern ever since (Stuiver et al. 1981; Bowen 1990; Schell and Ziemann 1989). Our objective was to determine if such a $\Delta^{14} \mathrm{C}$ signature existed in tree rings that should have formed in the early $1960 \mathrm{~s}$ based on their placement along the radial sequence of wood increment layers.

\section{MATERIALS AND METHODS}

Tree-ring samples were collected in cooperation with S Díaz Castro (CIBNOR, La Paz, Baja California Sur, Mexico) and D Stahle (Tree-Ring Laboratory, University of Arkansas) in November 1995. The field site $\left(23^{\circ} 36^{\prime} \mathrm{N}, 109^{\circ} 56^{\prime} \mathrm{W}\right)$ is in Sierra La Victoria, just north of Sierra La Laguna, at an elevation of $1500-1600 \mathrm{~m}$. A total of 27 wood cores from 13 trees were obtained using $40-50 \mathrm{~cm}$ long increment borers with a 4.3-5.2 mm internal diameter. All samples were taken from the main stem, about $1 \mathrm{~m}$ above the ground. Selected trees were locally dominant, with heights between 10 and $15 \mathrm{~m}$, and diameters between 30 and $50 \mathrm{~cm}$ at coring height. The outside of several trees had been scarred either by low-intensity fire or by local people for extracting resin. In the laboratory, cores were vertically aligned, then glued to grooved wooden mounts. Cores were surfaced using a belt sander and progressively finer sandpaper, until tracheid walls were clearly visible under a stereo-zoom binocular microscope. A large number $(>200)$ of growth layers could be counted on a single core, but no visual or numerical crossdating of tree-ring features could be established among samples. Tree rings, albeit visible, often have faint boundaries (Figure 1), and their width patterns do not match from one core to another, even when cores are from the same tree.

Three cores were selected for ${ }^{14} \mathrm{C}$ analysis (Figure 2). Each core was taken from a different tree. Two cores (SLV02A and SLV06B) belonged to young-looking trees on gentle terrain, while the 3rd core (VIC05B) belonged to an old-looking tree from a steep ravine where pines showed signs of stunted growth. Tentative dates were assigned to growth layers by assuming that the outermost ring (next to the bark) was formed in 1995, and that visible rings were annual. We manually picked 3 or 4 rings next to the estimated location of the mid 1960s, plus one more ring about 10 to 15 rings on either side of the main group (Figure 2). Leavitt and Danzer's (1993) method was used for homogenizing the wood and extracting the holocellulose. The holocellulose was then mixed with $\mathrm{CuO}$ in a 10:1 ratio by mass, and combusted in $\mathrm{Vycor}^{\circledR}$ tubing at $850{ }^{\circ} \mathrm{C}$ for $3-4 \mathrm{~h}$. The $\mathrm{CO}_{2}$ produced was cryogenically isolated, sealed in Pyrex ${ }^{\circledR}$ tubing, and shipped to the National Ocean Sciences AMS Facility at Woods Hole Oceanographic Institution for ${ }^{14} \mathrm{C}$ analyses. Given the small size of visible growth layers in $P$. lagunae wood samples, the AMS process was preferred to the conventional $\beta$-counting method. $\mathrm{CO}_{2}$ was reacted with a catalyst to form graphite, which was then pressed into targets and analyzed on the accelerator along with standards and process blanks. 


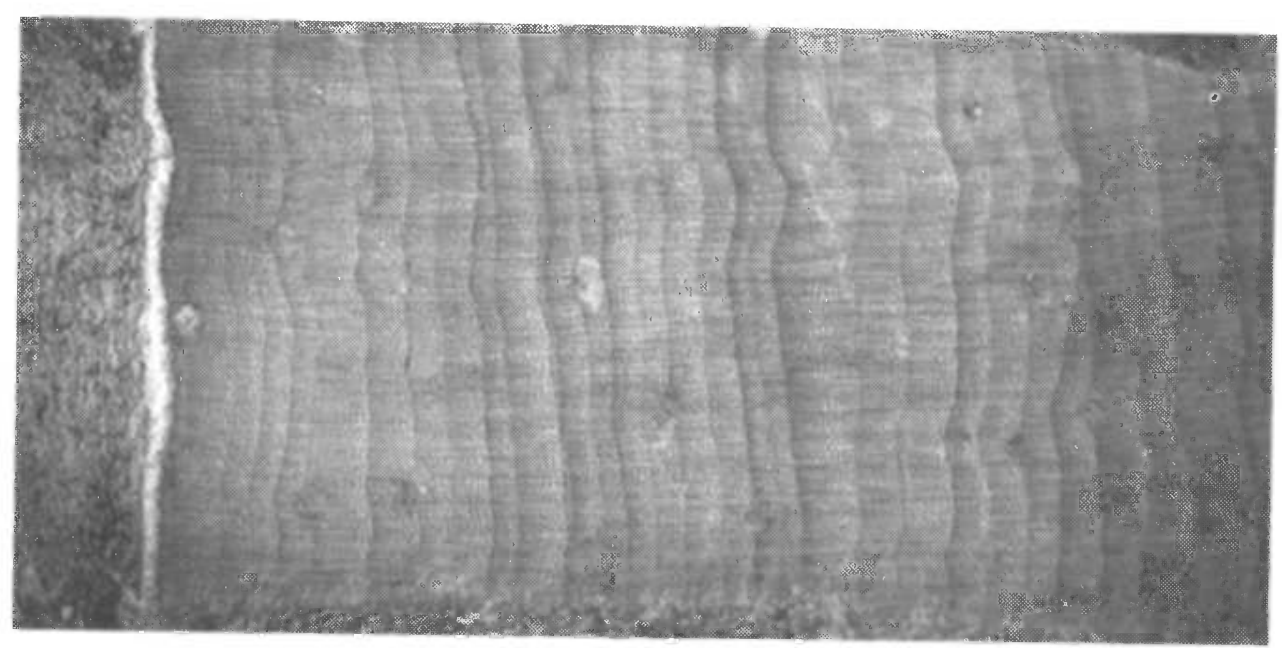

Figure 1 Growth layers of Pinus lagunae as seen on the monitor screen of our image analysis system. Outside bark is to the left.

\section{RESULTS}

Radiocarbon analyses are summarized in Table 1 and plotted in Figure 3. Initially, measured $\Delta^{14} \mathrm{C}$ was compared with its expected values from 1950 to 1992 (Stuiver and Polach 1977; personal communication, JR Southon, Lawrence Livermore National Laboratory, Center for AMS). It was evident that $\Delta^{14} \mathrm{C}$ measurements were not consistent with the preliminary dates assigned to the growth rings (Figure 3). More specifically, $\triangle^{14} \mathrm{C}$ values of SLV06B and VIC05B peak about $10 \mathrm{yr}$ later than expected. Therefore, the dates assigned to sampled rings must be shifted at least $10 \mathrm{yr}$ back in time to match expected $\Delta^{14} \mathrm{C}$ values. This shows that 10 or more extra rings had to be present besides those that were counted backwards from the bark on cores SLV06B and VIC05B, and the absence of those rings indicates that tree growth was severely limited by unfavorable conditions. Conversely, $\Delta^{14} \mathrm{C}$ values of SLV02A followed the reference curve more closely, but peaked a few years earlier than expected (Figure 3). Therefore, the dates assigned to sampled rings need to be shifted a few years forward in time. This demonstrates that a few extra rings were counted going from the bark toward the pith on core SLV02A, and the presence of those additional growth layers reveals that more than one growing season may occur within the same year.

To test these initial results, we sampled 2 more rings from each core (Figures 2 and 4). The rings were chosen to fill gaps in the $\Delta^{14} \mathrm{C}$ time series, and to validate the temporal shifts identified from the first set of sampled rings. As shown in Figure 4, the 2 additional $\Delta^{14} \mathrm{C}$ values for SLV06B were quite high, and clearly defined an $8-10 \mathrm{yr}$ difference from the reference curve. The 2 additional $\Delta^{14} \mathrm{C}$ values for VIC05B uncovered a slow rise in ${ }^{14} \mathrm{C}$ concentration, pointing to at least a 17 -yr divergence from the expected curve (Figure 4). Therefore, the number of locally absent rings in VIC05B was about twice as large as that in SLV06B, which agrees well with the much slower mean growth rate in VIC05B than in SLV06B. Measured $\triangle^{14} \mathrm{C}$ of the additional rings sampled on SLV02A fell almost exactly on the initial curve (Figures 3 and 4). This finding confirmed that the ring sequence of SLV02A was off by about 5 yr because of intra-annual growth bands. 

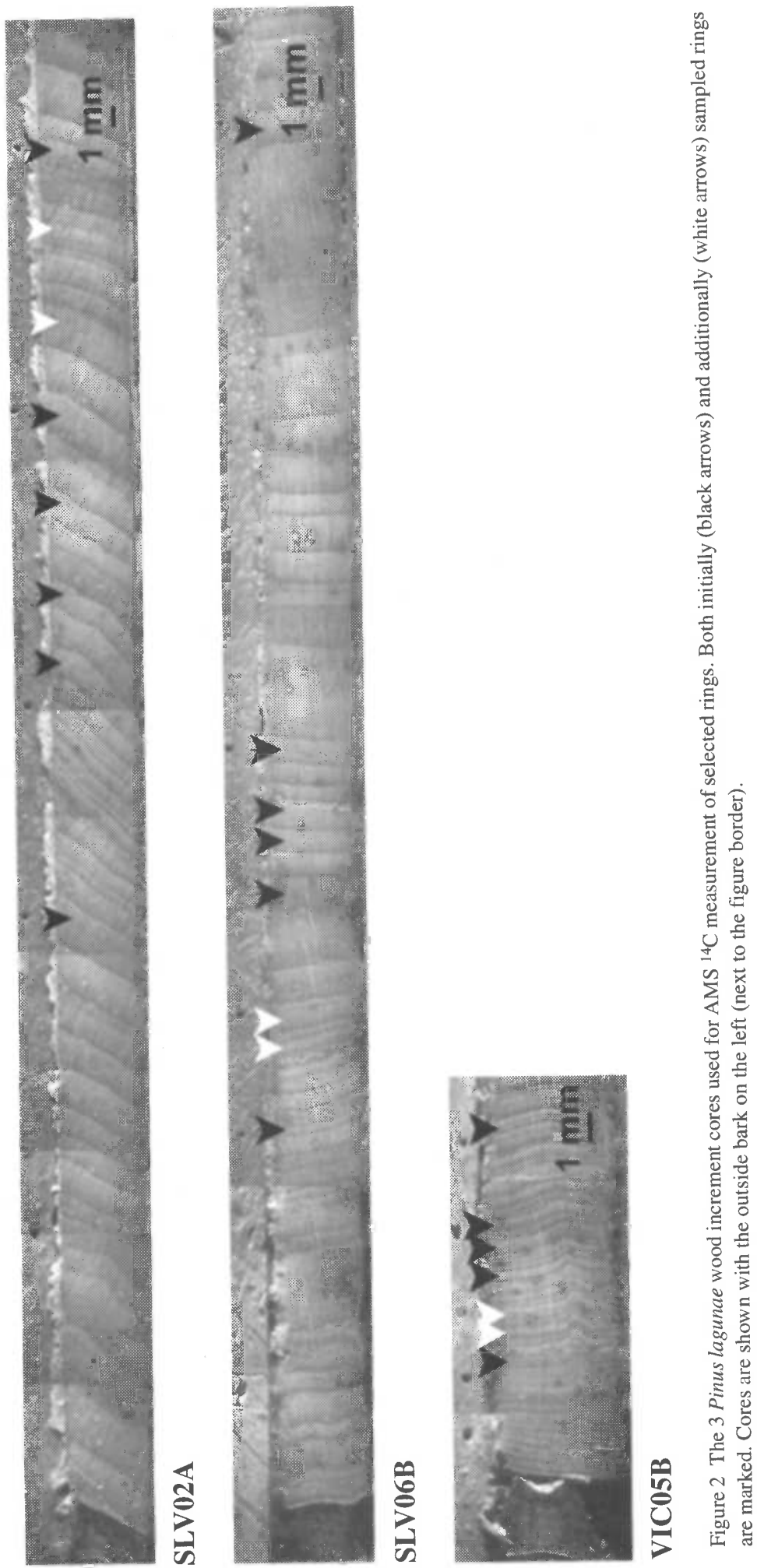
Table 1 AMS ${ }^{14} \mathrm{C}$ measurements on Pinus lagunae wood increment cores, including initially and additionally (in italics) sampled rings (Figure 2)

\begin{tabular}{lccccc}
\hline Core & $\begin{array}{c}\text { Estimated } \\
\text { year }^{\mathrm{a}}\end{array}$ & $\begin{array}{c}\mathrm{CO}_{2} \\
(\mathrm{~mL})\end{array}$ & $\begin{array}{c}\text { NOSAMS } \\
\text { number }\end{array}$ & $\begin{array}{c}\delta^{13} \mathrm{C} \\
(\%)\end{array}$ & $\begin{array}{r}\Delta^{14} \mathrm{C} \\
(\%)\end{array}$ \\
\hline SLV02A & 1980 & 0.82 & 19299 & -24.12 & 189 \\
SLV02A & 1967 & 1.80 & 19300 & -21.60 & 514 \\
SLV02A & 1965 & 2.23 & 19301 & -22.28 & 522 \\
SLV02A & 1963 & 2.75 & 19302 & -22.03 & 558 \\
SLV02A & 1960 & 2.74 & 19303 & -22.47 & 675 \\
SLV02A & 1950 & 2.60 & 19304 & -21.51 & 70 \\
SLV02A & 1954 & 1.09 & 21302 & -22.88 & 157 \\
SLV02A & 1958 & 1.00 & 21303 & -23.53 & 587 \\
& & & & & \\
SLV06B & 1980 & 2.42 & 19305 & -21.68 & 356 \\
SLV06B & 1967 & 2.75 & 19306 & -20.01 & 184 \\
SLV06B & 1965 & 2.73 & 19307 & -21.63 & 9 \\
SLV06B & 1963 & 2.75 & 19308 & -21.42 & -38 \\
SLV06B & 1960 & 2.65 & 19309 & -21.33 & -54 \\
SLV06B & 1950 & 2.71 & 19310 & $(-21.00)^{\mathrm{b}}$ & -27 \\
SLV06B & 1971 & 0.74 & 21304 & -22.42 & 624 \\
SLV06B & 1973 & 1.40 & 21305 & -22.22 & 662 \\
& & & & & \\
VIC05B & 1980 & 1.43 & 19311 & -21.31 & 347 \\
VIC05B & 1967 & $0.46^{\mathrm{c}}$ & 19312 & -20.82 & -78 \\
VIC05B & 1963 & 2.61 & 19313 & -20.61 & -28 \\
VIC05B & 1961 & 2.02 & 19314 & -20.72 & -43 \\
VIC05B & 1950 & 1.50 & 19315 & -19.59 & -49 \\
VIC05B & 1974 & 1.45 & 21306 & -21.14 & 6 \\
VIC05B & 1977 & 0.64 & 21307 & $(-25.00)^{\mathrm{b}}$ & 255 \\
\hline
\end{tabular}

a Estimated year of formation, based on the number of identified rings from the outside bark.

${ }^{\mathrm{b}}$ Estimated.

${ }^{c}$ Diluted.

\section{DISCUSSION}

The absence of crossdating among ring patterns had already shown that Pinus lagunae xylem layers at the study area could not be accurately assigned to calendar years. It was also likely that trees showing signs of old age and stunted growth (such as VIC05) would not form growth layers at the base of the stem during unfavorable years (Fritts 1976). It is puzzling, however, that trees with apparently similar mean growth rates would either include extra rings (SLV02) or skip growth years (SLV06).

Climate regime at the study area is likely to be the main cause for the asynchronous wood growth among P. lagunae individuals. Based on data from 1944 to 1983 for the city of La Paz (Figure 5), about $70 \mathrm{~km}$ to the north, mean annual temperature is $23.5^{\circ} \mathrm{C}$, with mean monthly temperature ranging from $17.4^{\circ} \mathrm{C}$ in January to $29.7^{\circ} \mathrm{C}$ in August. Total precipitation averages $159 \mathrm{~mm}$ annually; monthly it ranges from $1 \mathrm{~mm}$ in April to $48 \mathrm{~mm}$ in September. While the warm temperatures should not limit tree growth at any time of the year, precipitation is scarce, and tends to have 2 separate 
$\Delta^{14} \mathrm{C}$

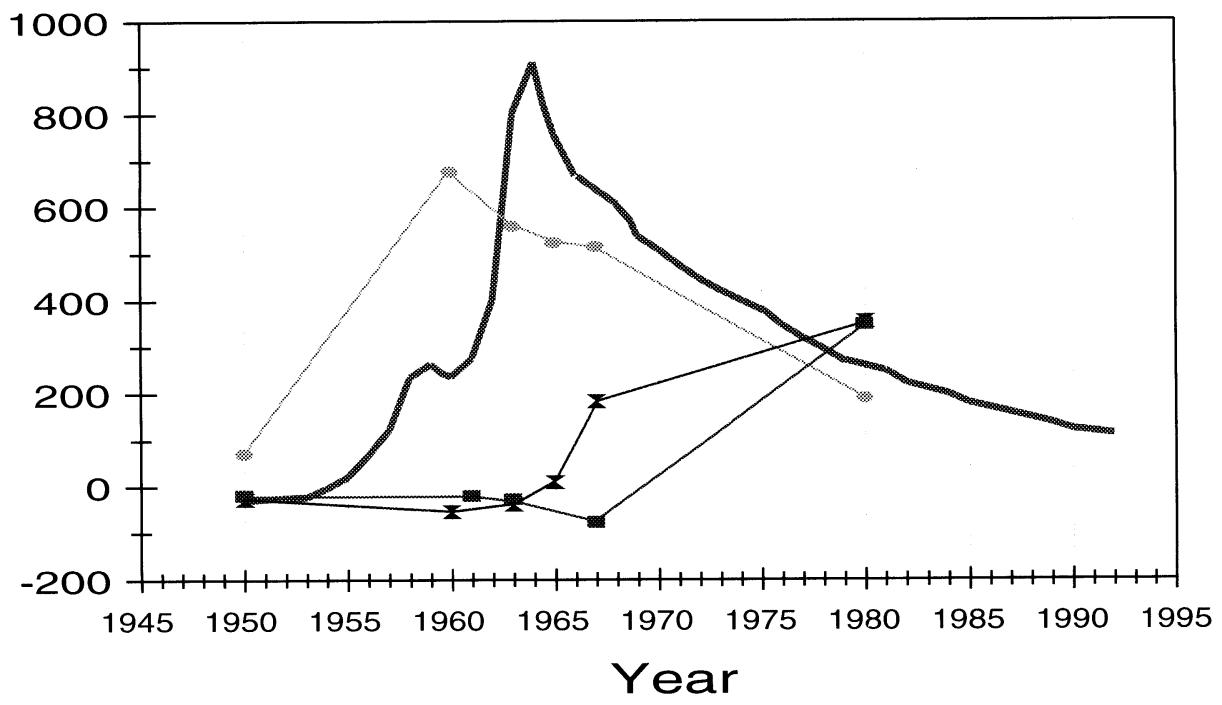

\section{Expected $\rightarrow$ SLV02A $\rightarrow$ SLV06B $\rightarrow$ VIC05B}

Figure 3 Plot of $\Delta^{14} \mathrm{C}(\%)$ measurements on initially sampled rings of wood increment cores (Table 1) compared to expected values provided by John R. Southon (Lawrence Livermore National Laboratory, Center for AMS, personal communication)

$\Delta^{14} \mathrm{C}$

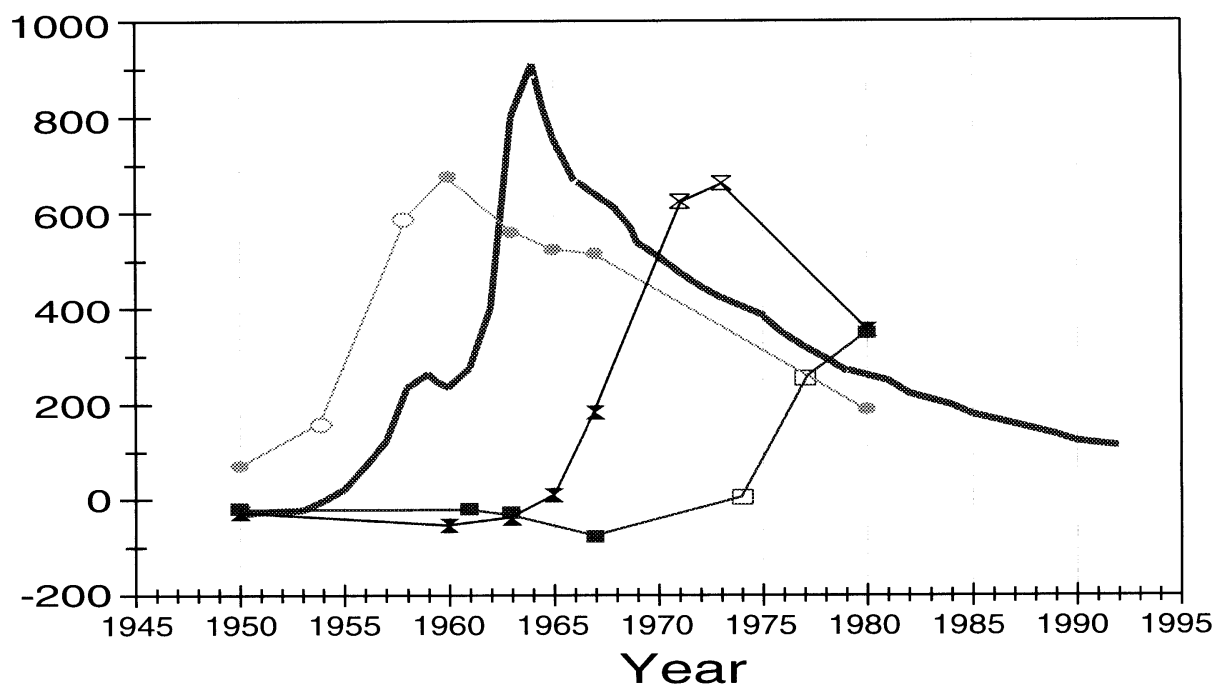

\section{Expected $\rightarrow$ SLV02A $\rightarrow$ SLV06B $\rightarrow$ VIC05B}

Figure 4 Same as Figure 3, with both initially (filled symbols) and additionally (empty symbols) sampled rings (Table 1) 

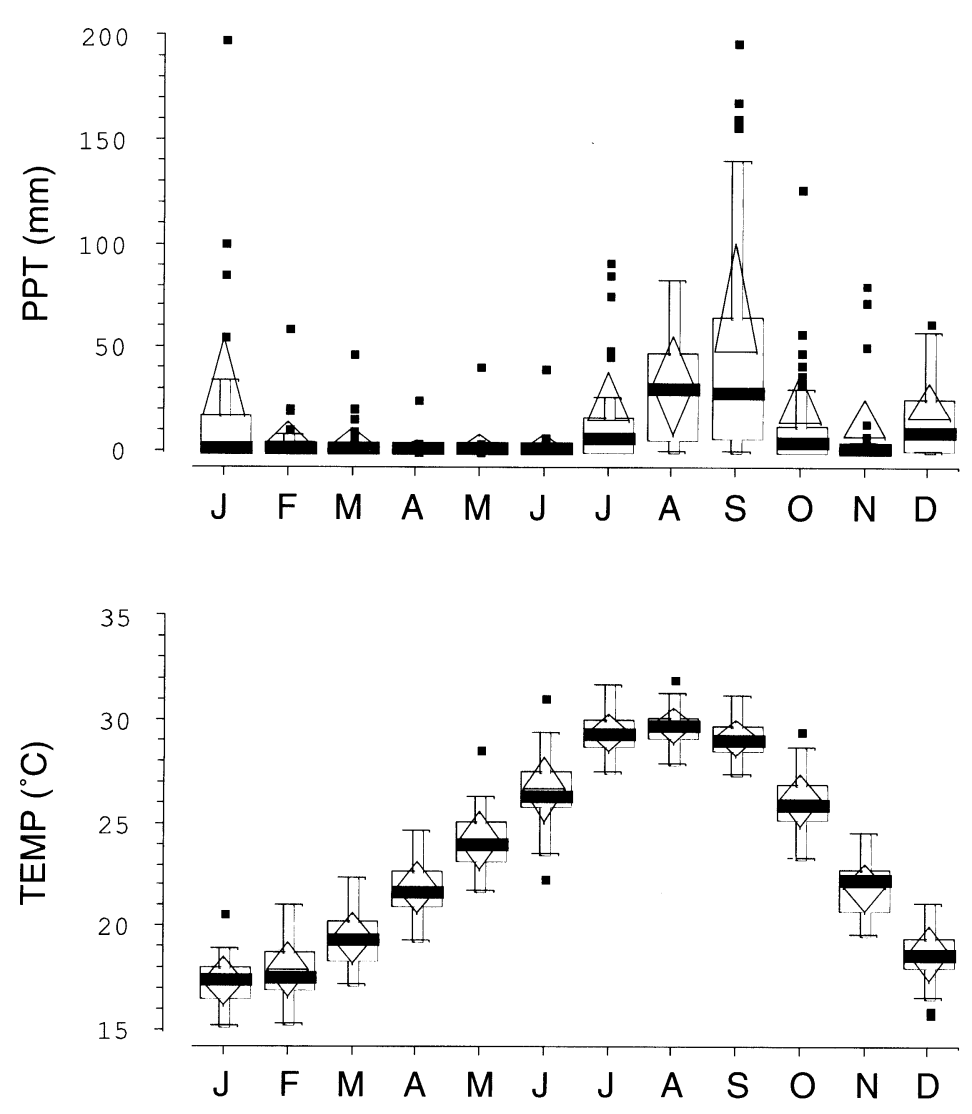

Figure 5. Climatic diagram for La Paz $\left(24^{\circ} 10^{\prime} \mathrm{N}, 110^{\circ} 17^{\prime} \mathrm{W}, 32 \mathrm{~m}\right.$ elevation) from 1944 to 1983 (source: PACLIM data set, Cayan et al. 1991). Box-whisker symbols (SAS Institute 1990) for each monthly variable show the median (heavy horizontal line), the 25 th and 75 th percentiles (bottom and top edges of the box, respectively), the mean \pm 1 standard deviation (base and vertex of triangle, respectively), the last point within 1.5 interquartile ranges from the 25 th and 75 th percentiles (vertical bars below and above the box, respectively), and the extreme values (solid squares).

peaks, a major one in late summer/early fall, and a minor one in winter (Figure 5). Assuming a water-year spanning the previous November to the current October, $28 \%$ of total precipitation falls during the winter (November-February) and 69\% during the summer/fall (June-October). Such a climate regime is intermediate between that of San Diego (Southern California, USA), where November to February precipitation accounts for $65 \%$ of the total, and the climate regime of Colima (Colima, Mexico), where $91 \%$ of precipitation falls from June to October. It is therefore possible that seasonal drought is responsible for the absence of visible growth layers at the base of some pine stems, especially when combined with limited soil buffering because of a steep and/or rocky slope. At the same time, depending on individual features of the trees and on microsite conditions, separate wet periods could generate distinct growth layers within the same year in other trees.

Note that, despite such dating problems at the annual level, multiannual ring-width patterns could still correspond from core to core. For instance, there is a series of about 10 consecutive small rings in both SLV02A (between the first 2 sampled rings nearest to the bark; Figure 2) and in SLV06B (between the first initial and the first additional sampled ring nearest to the bark; Figure 2) that are 
likely to represent the same time period. This loosely defined pattern matching, which is not uncommon when dating ocean laminated sediments (personal communication, JC Herguera, CICESE), is perhaps feasible here as well, but it must not be confused with dendrochronological crossdating, which assigns an exact calendar year to every wood increment (Douglass 1941; Stokes and Smiley 1968; Baillie and Pilcher 1973; Holmes 1983).

The present study provides a clear example of how AMS ${ }^{14} \mathrm{C}$ measurements can be used to test for the presence of annual rings when crossdating fails. We demonstrated that ring-width patterns of sampled Pinus lagunae were not consistent from one tree to another, and we accurately uncovered their divergence from expected values. Most likely, microsite conditions are more important than regional climate as limiting factors for tree growth. Earlier dendrochronological studies (Díaz et al. 1994; Díaz 1995) were based on vigorous trees with no scars and regular shape growing on gently sloping terrain at higher elevations. Ongoing research at the Laboratory of Tree-Ring Research in Tucson, Arizona, indicates that a great deal of time and effort from highly experienced personnel is required to analyze $P$. lagunae samples using standard dendrochronological techniques. For the purpose of developing dendrochronological proxy records of climate from coniferous species in tropical North America, we thus recommend focusing on species and sites that experience a more pronounced seasonality, such as those found at timberline on the high peaks of Central America (Perry 1991; Arno and Hammerly 1984).

\section{ACKNOWLEDGMENTS}

We thank the Mexican authorities for permission to obtain tree-ring samples. Field collections were made in cooperation with S Díaz Castro (CIBNOR, La Paz, Baja California Sur, Mexico) and D Stahle (Tree-Ring Laboratory, University of Arkansas, Fayetteville). Funding for ${ }^{14} \mathrm{C}$ analyses was provided by the NOSAMS Research Initiatives Program. F Biondi was supported by a grant from the National Oceanic and Atmospheric Administration, by a G Unger Vetlesen Foundation grant to Scripps Institution of Oceanography, and by the InterAmerican Institute for Global Change Research. The comments of John Hayes, Ann McNichol, and one anonymous reviewer are gratefully acknowledged.

\section{REFERENCES}

Adams DK, Comrie AC. 1997. The North American monsoon. Bulletin of the American Meteorological Society 78:2197-213.

Arno SF, Hammerly RP. 1984. Timberline: mountain and arctic forest frontiers. Seattle: The Mountaineers. 304 p.

Baillie MGL, Pilcher JR. 1973. A simple cross-dating program for tree-ring research. Tree-Ring Bulletin 33: 7-14.

Berner EK, Berner RA. 1987. The global water cycle: geochemistry and environment. Englewood Cliffs (NJ): Prentice-Hall. 397 p.

Biondi F, Galindo Estrada I, Burton A, Metcalfe SE, Cayan DR, Berger WH. 1999. A 400-year tree-ring chronology from the North American tropics. In: Karl TR, editor. Proceedings of the 10th Symposium on Global Change Studies. Boston: American Meteorological Society. p 161-2.

Bormann FH, Berlyn G, editors. 1981. Age and growth rate of tropical trees: new directions for research. New
Haven: Yale University. 137 p. (School of Forestry and Environmental Studies; bulletin 94).

Bowen R. 1990. Isotopes and climates. New York: Elsevier. 483 p.

Bowman, S. 1990. Radiocarbon dating. London: British Museum Publications. 64 p. (Interpreting the past series; 1 ).

Buckley B, Barbetti M, Watanasak M, D'Arrigo R, Boonchirdchoo S, Sarutanon S. 1995. Preliminary dendrochronological investigations in Thailand. IAWA Bulletin 16:393-409.

Cayan DR, McLain DR, Nichols WD, DiLeo-Stevens JS. 1991. Monthly climatic time series data for the Pacific Ocean and Western Americas. US Geological Survey Open-File Report 91-92, Menlo Park, California.

D’Arrigo R, Jacoby G, Krusic P. 1994. Frogress in dendroclimatic studies in Indonesia. Terrestrial, Atmospheric and Oceanic Sciences 5:349-63.

Diaz HF, Kiladis GN. 1992. Atmospheric teleconnections associated with the extreme phases of the South- 
ern Oscillation. In: Diaz HF, Markgraf V, editors. $E l$ Niño: historical and paleoclimatic aspects of the Southern Oscillation. Cambridge: Cambridge University Press. p 7-28.

Diaz HF, Markgraf V, editors. 1992. El Niño: historical and paleoclimatic aspects of the southern oscillation. Cambridge: Cambridge University Press. 476 p.

Díaz SC. 1995. Dinámica poblacional y análisis dendrocronológico de una especie de conífera endémica, $P i$ nus lagunae M.-F. Passini de Baja California Sur [master's thesis]. México, DF: Universidad Nacional Autónoma de México.

Díaz SC, Salinas-Zavala CA, Arriaga L. 1994. An interannual climatological aridity series for the Sierra de la Laguna, B.C.S. Mexico. Mountain Research and Development 14:137-46.

Douglas MW, Maddox RA, Howard KH. 1993. Climatological aspects of the Mexican monsoon. Proceedings of the 17th Annual Climate Diagnostic and Prediction Workshop. Washington (DC): NOAA. p 135-40.

Douglass AE. 1941. Crossdating in dendrochronology. Journal of Forestry 39:825-31.

Fritts HC. 1976. Tree rings and climate. London: Academic Press. 567 p.

Holmes RL. 1983. Computer-assisted quality control in tree-ring dating and measurement. Tree-Ring Bulletin 43:69-78.

Leavitt SW, Danzer SR. 1993. Method for batch processing small wood samples to holocellulose for stablecarbon isotope analysis. Analytical Chemistry 65:879.

Metcalfe SE. 1987. Historical data and climatic change in Mexico - a review. The Geographical Journal 153:
211-22.

Mosino PA Garcia E. 1974. The climate of Mexico. In: Bryson RA, Hare FK, editors. Climates of North America. New York: Elsevier. p. 345-404.

Perry PJ Jr. 1991. The pines of Mexico and Central America. Portland: Timber Press. 231 p.

Rzedowski J, McVaugh R. 1966. La vegetación de Nueva Galicia. Contributions from the University of Michigan Herbarium 9:1-123.

SAS Institute. 1990. SAS/GRAPH software: reference, version 6. 1st ed. Vol 1. Cary (NC): SAS Institute. 794 p.

Schell DM, Ziemann PJ. 1989. Stable isotopes in ecological research. New York: Springer-Verlag. 525 p.

Stahle DW, Cleaveland MK. 1993. Southern Oscillation extremes reconstructed from tree rings of the Sierra Madre Occidental and Southern Great Plains. Journal of Climate 6:129-40.

Stahle DW, D'Arrigo RD, Krusic PJ, Cleaveland MK, Cook ER and others. 1998. Experimental dendroclimatic reconstruction of the Southern Oscillation. Bulletin of the American Meteorological Society 79: 2137-52.

Stokes MA, Smiley TL. 1968. An introduction to treering dating. Chicago: University of Chicago Press. 73 p.

Stuiver M, Polach HA. 1977. Reporting of ${ }^{14} \mathrm{C}$ data. Radiocarbon 19(3):355-63.

Stuiver M, Rebello A, White JC, Broecker W. 1981. Isotopic indicators of age/growth in tropical trees. New Haven: Yale University. p. 75-82. (School of Forestry and Environmental Studies; bulletin 94). 